\title{
PERAN ORANG TUA DALAM MEMINIMALKAN PERILAKU DISRUPTIF
}

\author{
Mudhar \\ Prodi Bimbingan dan Konseling FKIP Universitas PGRI Adi Buana Surabaya \\ Email: mudhar.bps@gmail.com
}

\begin{abstract}
Disruptive behavior is a form of behavior that many children do both verbally and non-verbally, such as raging, seeking attention, talking to his friends, and other annoying behavior. Disruptive behavior in early childhood often continues until later adulthood. Students with disruptive behavior raises concerns for families, schools, and communities. In particular, students with many performing annoying behaviors will experience more academic difficulties including. Many studies that explain the importance of parents in the process of child development, including in reducing the disruptive behavior of children. Although disruptive behavior in children is normal and normal, but if this issue is allowed to continue, it will have a greater negative impact. This paper will discuss the importance of parent-child relationships to minimize the disruptive behavior of children. In the process of interaction of children with parents there imitation process. The child's imitation of the behavior of one parent is a very possible manifestation of indirect influence in the family system. When his parents behaved brusquely to his son or to others, it is possible that his son will also imitate such things to others. In addition, family involvement is defined as the active involvement of family members, especially parents in the activities and behaviors of children at home and at school will be beneficial in their child's development, family involvement and parents will have an impact on the academic, psychological, social and positive behaviors others, including reducing disruptive behavior in children.
\end{abstract}

Keywords: Role of parent, disruptive behavior

\section{PENDAHULUAN}

Perilaku mengganggu atau disruptive behavior, seperti halnya agresi, pembangkangan, dan amarah, adalah beberapa masalah yang paling umum terlihat pada anak-anak. (Strassberg, Kees, \& Drabick, 2002). Perilaku mengganggu dapat diartikan sebagai serangkaian tingkah laku tidak pantas (inappropriate) yang beragam meliputi, merengek atau menangis berlebihan, menuntut perhatian, tidak patuh, menantang, tindakan agresif yang membahayakan diri sendiri atau orang lain, pencurian, berbohong, pengrusakan barang, dan delikuensi (Schroeder \& Gordon, 2002). Siswa dengan perilaku yang mengganggu akan menimbulkan keprihatinan tersendiri baik bagi keluarga, sekolah, maupun masyarakat. Perilaku mengganggu pada anak usia dini sering berkelanjutan dan akan menyebabkan kesehatan mental negatif di kemudian hari, mulai dari perilaku agresif, penyalahgunaan narkoba dan kriminalitas lainnya. Mungkin masih ingat kasus penganiayaan siswa SMAN 1 Torjun Sampang terhadap gurunyaAhmad Budi Cahyono sampai meninggal dunia. Siswa SMA Negeri 1 Kubu Raya Kalimatan Barat yang memukul gurunnya dengan kursi. Siswa SD yang menantang seorang guru ketika sedang akan diperingatkan dan dinisehati, bahkan menatap tajam gurunya sembari membusungkan dada(Putri, 2018), dan mungkin masih banyak lagi kasus-kasus serupa.

Masalah perilaku menjadi persoalan tersendiri, baik disekolah maupun di lingkungan keluarga. Perilaku mengganggu atau surface behavior (Levin \& Nolan, 1996)adalah gangguan perilaku yg paling 
umum, yang meliputi: a. verbal interruption (berbicara, menggumam, tertawa, berteriak, berbisik), b. off-task behavior (melamun, tidur, menyisir rambut, memainkan sesuatu, menggambar), c. pergerakan fisik yang mengganggu siswa lain (berkunjung, melempar catatan, duduk diatas meja atau menaikkan kaki diatas kursi, melempar kertas), d. dan tidak menghargai guru ataupun siswa lain (berdebat, mengejek, bergosip). Perilaku ini disebut sebagai surface behaviours karena masalah ini bukan hasil dari problem kepribadian (perilaku yang tampak) tetapi merupakan perkembangan perilaku normal dari anak-anak, namun demikian, permasalahan ini cenderung mengganggu dalam proses belajar dan mengajar.

Sebuah penelitian yang dilakukan oleh California Departemen Pendidikan pada tahun 1992 (Flicker \& Hoffman, 2006) membandingkan masalah pendisiplinan di sekolah-sekolah di tahun 1940-an dan 1980an. Hasil mengungkapkan bahwa pada 1940an guru berfokus pada masalah seperti menyuruh anak-anak tetap antri dan membuang sampah. Namun, pada tahun 1980-an, para guru berurusan dengan penggunaan narkoba, agresi, mencuri, dan pergaulan bebas.

Jika dilihat, siswa dengan perilaku mengganggu mengalami lebih banyak kesulitan akademik di sekolah (Reinke, Herman, Petras, \& Ialongo, 2008), akan terjadi putus sekolah, sebaik-baiknya anak yang memiliki perilaku mengganggu akan mendapatkan nilai akademik yang lebih rendah dan nilai prestasi yang rendah (Bub, McCartney, \& Willett, 2007).Siswa-siswa ini juga menunjukkan tingkat yang lebih tinggi dari faktor risiko termasuk sekolah ketidakmampuan dalam menyesuaikan diri, perilaku yang antisosial, bahkan penggunaan narkoba. Siswa dengan masalah perilaku mengganggu kemungkinan akan beresiko untuk mengalami berbagai hal kehidupan yang negatif, oleh karena itu sangat penting untuk mengidentifikasi faktor-faktor mempengaruhi perilaku mengganggu ini.

\section{PERILAKU MENGGANGGU}

Disruftive behavioratau perilaku mengganggu dapat didefinisikan sebagai perilaku tampak yang terjadi di dalam kelas yang menganggu guru dan atau siswa yang lain, contohnya yaitu menolak berpartisipasi atau bekerjasama dalam kegiatan kelas, mengabaikan hak orang lain, tidak memperhatikan pelajaran, membuat keributan dan meninggalkan tempat duduk tanpa ijin (Bidell \& Deacon, 2010). Sejalan dengan pengertian ini Levin \& Nolan (1996) mengemukakan istilah surface behavior(perilaku permuakaan), dikatakan perilaku permukaan karena bukan kepribadian yang dalam, perilaku ini merupakan perkembangan perilaku normal dari anak-anak. Walaupun demikian, permasalahan ini cenderung mengganggu baik untuk belajar dan pembelajaran, dan jika dibiarkan akan menjadi persoalan yang berat dimasa yang akan datang.Surface behavior meliputi verbal interruption (berbicara, menggumam, tertawa, berteriak, berbisik), off-task behavior (melamun, tidur, menyisir rambut, memainkan sesuatu, menggambar), pergerakan fisik yg mengganggu siswa lain (berkunjung, melempar catatan, duduk diatas meja atau menaikkan kaki diatas kursi, melempar kertas), dan tidak menghargai guru ataupun siswa lain (berdebat, mengejek, bergosip).

Perilaku mengganggu siswa dapat dipengaruhi oleh beberapafaktor. Menurut (Flicker \& Hoffman, 2006) menyebutkanbeberapa faktor yang menyebabkan anak berperilaku mengganggu antara lain faktor emosional yang mencakup di dalamnya kepribadiantemperamental, kemarahan, penentangan, ketegasan, frustrasi,kecemasan, ketakutan, kebosanan, overstimulasi, kebutuhan akanperhatian, kecemburuan, dan rendah diri. Faktor fisiologis yang mencakupdi dalamnya gizi buruk, kelaparan, kelelahan, penyakit, dan alergi. Keduafaktor tersebut dapat disimpulkan sebagai faktor internal atau faktor yangberasal dari dalam diri individu.

Menurut Mabeba \& Prinsloo (2000) perilaku mengganggu disebabkan oleh 
masalah disiplin di sekolah yang mempengaruhi hak-hak dasar pelajar akan rasa aman dan diperlakukan yang menghormati dalam lingkungan belajar. Melihat hasil penelitian yang dilakukan oleh California Departemen Pendidikan pada tahun 1992 (Flicker \& Hoffman, 2006) bahwa terjadi pergeseran perilaku disiplin dari tahun ketahun. Perilaku anak-anak dirasakan di masa lalu telah berevolusi dari tahun ke tahun hingga saat ini. Perilaku anakanak dan tanggapan orang dewasa selalu didasarkan pada pengaruh sosiologis, filosofis, dan psikologis pada hari itu. Sekolah juga merupakan cerminan dari kecenderungan masyarakat itu sendiri. Baik guru dan anak-anak adalah produk dari latar belakang mereka sendiri, latar belakang budaya, dan praktik disiplin, dan dinamika ini sering dimainkan di lingkungan sekolah (Flicker \& Hoffman, 2006).

Menurut beberapa ahli (Todras, 2007) perilakumengganggu di kelas bisa disebabkan dari faktor eksternal yaitu kondisi dirumah, masyarakat, dan sekolah. Pengalaman anak di rumah secarasignifikan dapat mempengaruhi perilaku mereka di sekolah, khususnya bagikorban perceraian, kemiskinan, kurangnya keterlibatan orang tua,kurangnya pengawasan, kurangnya perhatian dan dorongan, penelantaranorang tua, kontrol berlebihan dan hukuman fisik dapat berakibat burukterhadap individu atau kemampuannya untuk tampil di sekolah.

Orangtuaseringkali mengabaikan tingkah laku anak ketika mereka berperilaku baikdan tidak mengganggu. Akan tetapi, perhatian orang tua hanya diberikanketika anak melakukan kenakalan. Perilaku orang tua yang demikian akanmendorong anak untuk berperilaku tidak baik di sekolah karena anakmengganggap bahwa satusatunya cara mereka mendapatkan perhatianyang mereka butuhkan adalah dengan melakukan kenakalan. Hasil penelitian Marais \& Meier, (2010) menemukan bahwa anak yang disruptive behavior disekolah tidak hanya disebabkan oleh suasana sekolah, tetapi yang lebih berperan adalah pola asuh orang tua yang tidak memberikan pengetahuan tentang moral, nilai-nilai kesopanan, etika dan konsep berpikir tentang perilaku mengganggu. Orang tua kurang bertanggung jawab dengan pendidikan moral anak, meski anak nakal tidak dibimbing, hingga disekolah anak tetap saja nakal dan mengembangkan disruptive behavior disekolahnya.

Sejalan dengan teori dari Skinner tentang reward and punishment,(Kohn, 1999)bahwa pemberianreward andpunishmentyang berlebihan dari guru jugadapat berpengaruh negatif terhadap perilaku siswa. Meskipun adapembenaran untuk menggunakan teknik modifikasi perilaku pada situasitertentu, guru biasanya hanya mengatasi perilaku pada saat itu dan bukanpenyebabnya. Jadi, apabila tidak ada usaha dari diri siswa mengatasimasalahnya yang mendasar, maka rencana modifikasi perilaku pun menjaditidak efektif lagi.

\section{KEBERADAAN ORANG TUA}

Orang banyak berfikir bahwa pengasuhan, hanya sebatas mengganti popok, menyuapi makan, mengajaknya bermain, atau membelikannya mainan. Pengasuhan anak jauh dari sekedar memberikan dan memenuhi kebutuhan hidup dasar anak, dan keluarga terutama orang tua memiliki pengaruh signifikan terhadap bagaimana anak-anak tumbuh dan berkembang, termasuk kepribadian mereka, perkembangan emosi, dan kebiasaan-kebiasaan perilaku, serta sejumlah faktor lainnya. Penting bagi perkembangan keseluruhan anak-anak bahwa orang tua cukup hadir untuk mendukung mereka, dan dukungan ini menumbuhkan kepercayaan diri dan pertumbuhan di banyak bidang.

Keluarga sebagai tempat pertama dalam berinteraksi bagi anak ketika sudah lahir ke dunia, keluarga akan memberikan pengalaman pertama dalam hidup. Pembelajaran pertama yang diperoleh anak dari orang tua, sebagai pendidik yang pertama dan utama dalam kehidupan anak akan banyak membantu pengembangan potensi siswa-siswanya. Banyak hal yang dapat dan harus dilakukan orang tua dalam 
membantu proses pendidikan anak-anaknya termasuk dalam pengembangan karirnya. Terkadang orang tua hadir secara fisik didekat anak-anaknya, akan tetapi tidak secara emosional atau responsif dalam membesarkan anak-anak, kurang terlibat dengan kegiatan mereka.

Orang tua memainkan peran penting dalam perkembangan anak-anak saat mereka tumbuh menjadi dewasa dan belajar bagaimana untuk menavigasi diri dalam kehidupannya. Salah satu peran utama yang orang tua bermain untuk anak-anak mereka adalah pengaruh pada bagaimana pendidikan harus dikejar dan dicapai sepanjang seumur hidup (Ruholt, Gore, \& Dukes, 2015).

Manusia adalah makhluk sosial, dalam kehidupan sosial, anak-anak secara terus menerus belajar untuk mengadopsi peran mereka dalam masyarakat. Ketika masa kanak-kanak sampai mencapai usia remaja, mereka berhadapan dengan berbagai lapisan kehidupan sosial, eksplorasi pengetahuan diperoleh melalui berbagai sumber. Orang tua mereka adalah sumber utama dari pengetahuan mereka. Orang tua adalah pembentuk kepribadian yang paling utama bagi anak-anak mereka.

Kadang-kadang orang tua hanya hadir secara fisik saja, hal itu tidak cukup. Orangtua yang mungkin berada di dekatnya namun tidak tercurahkan sepenuhnya. Keterlibatan emosional orang tua juga merupakan hal penting dan mempengaruhi regulasi emosil anak. Orang tua harus mengingat hal ini dan mempertimbangkan kualitas waktu yang mereka habiskan bersama anak-anaknya, karena jika mereka cukup memberikan waktu dan komitmen, anak akan belajar mengatur emosinya dan berinteraksi dengan orang lain dengan tepat. Anak-anak melihat bagaimana orang tua mereka menampilkan emosi dan berinteraksi dengan orang lain, dan mereka meniru apa yang mereka lihat orang tua mereka lakukan untuk mengatur emosi.

Aspek kunci dari perkembangan emosi pada anak adalah belajar bagaimana mengatur emosi. Anak-anak melihat bagaimana orang tua mereka menampilkan emosi dan berinteraksi dengan orang lain, dan mereka meniru apa yang mereka lihat orang tua mereka lakukan untuk mengatur emosi (Morris et al., 2007). Orangtua harus menyadari bahwa tidak hanya emosi dan gaya pengasuhan mereka yang mempengaruhi emosional anak-anak mereka. Membimbing emosi anak dan membantu mereka menemukan cara untuk mengekspresikan diri mereka dengan cara yang sehat akan membantu anak-anak mereka untuk terus mampu menanggapi tantangan dan sosial mereka. Pelatihan emosi semacam ini sangat membantu dalam mengurangi perilaku masalah di masa depan pada anak-anak.

Keterlibatan keluarga didefinisikan sebagai keterlibatan aktif dari anggota keluarga dalam kegiatan dan perilaku di rumah dan di sekolah untuk manfaat pembelajaran dan perkembangan anak mereka (Fantuzzo, Tighe, \& Childs, 2000), keterlibatan keluarga dalam belajar anak terkait dengan sejumlah hasil akademik, psikologis, sosial, dan perilaku positif bagi semua anak, termasuk mereka yang perilaku mengganggu.

Pendidikan anak bukanlah sematamata tanggung jawab sekolah, orang tua juga memegang peran penting dalam pendidikan anak. Sebagian besar waktu anak banyak berinteraksi dengan lingkungan keluarga. Pusat pendidikan yang pertama adalah lingkungan keluarga, pendidikan di lingkungan keluarga sangat strategis untuk memberikan pendidikan ke arah kecerdasan, budi pekerti atau kepribadian serta persiapan hidup di masyarakat. Orang tua akan menjadi contoh bagi anak, anak biasanya akan menirukan apa saja yang dilakukan oleh orang tua. Jadi orang tua harus bisa memberikan keteladanan dan kebiasaan sehari-hari yang baik sehingga dapat dijadikan contoh bagi anaknya. Keteladanan dan kebiasaan yang baik itu, sebaiknya diberikan oleh orang tua sejak dari kecil atau kanak-kanak karena hal itu dapat berpengaruh terhadap perkembangan jiwa anak.Imitasi anak dari perilaku antara anggota keluarga yang terhadap yang 
lainmerupakan manifestasi yang mungkin terjadi sebagai pengaruh tidak langsung dalam sistem keluarga (Goldberg \& Easterbrooks, 1984).

\section{PENGASUHAN DAN PERILAKU DISRUFTIF}

Pengasuhan anak jauh dari sekedar memberikan dan memenuhi kebutuhan hidup dasar anak, dan keluarga terutama orang tua adalah lingkungan tersekat yang berpengaruh signifikan terhadap tumbuh kembang anak, termasuk kepribadian, perkembangan emosi, kebiasaan-kebiasaan perilaku, dan faktor lainnya. Kohn (1999) menyatakan bahwa pola asuh merupakan sikap orang tua dalam berinteraksi dengan anak-anaknya. Sikap orang tua ini termasuk cara-cara orang tua dalam memberikan aturan-aturan, memberikan hadiah, hukuman yang menunjukkan otoritasnya terhadap anakanaknya. Banyak perilaku yang ditampilkan oleh orang tua dan dilihat oleh anak-anaknya, baik yang sengaja untuk ditiru maupun yang tidak disengaja. Hasil penelitian Stormshak, Bierman, McMahon, \& Lengua (2000) rendahnya tingkat keterlibatan orang tua yang hangat dan khusus menunjukkan peningkatan kadar perilaku oposisi bagi anak.

Menurut Bandura bahwa perilaku baru dapat dicapai lewat dua jenis pembelajaran, yaitu pembelajaran dengan bertindak dan pembelajaran dengan mengamati. Enactive Learning atau dapat dikatakan pembelajaran dengan bertindak, belajar dari akibat atas tindakannya sendiri. Perilaku yang menghasilkan akan dipertahankan, sedangkan perilaku yang dianggap kurang berhasil akan ditinggalkan. Disini berbeda dengan teori kondisioning, karena akibat dari perilaku itu akan menjadi informasi dan motivasi. Perilaku yang dapat memberikan imbalan bermakna bahwa perilaku itu benar, sedangkan perilaku atau tindakan yang berakibat negatif akan memberikan informasi bahwa tindakan itu salah.

Banyak peneliti yang telah menjelaskan hubungan antara praktek agresif secara fisik orang tua dengan peningkatan kadar agresi anak di rumah maupun sekolah. Marais \& Meier(2010)menyatakan bahwa menunjukkan kurangnya perhatian orang tua, kurangnya keterlibatan orang tua, dan kurangnya model peran sebagai penyebab signifikan perilaku mengganggu.Orang tua harus menjadi contoh dari nilai-nilai dan keyakinan murni. Semua perilaku yang diamati oleh anak-anaknya akan menjadi pembelajaran oleh si anak. Sepanjang sejarah, orang menganggap imitasi sebagai sarana penting untuk mewariskan perilaku. Perspektif lain tentang imitasi menghubungkannya dengan insting, pengembangan, pengkondisian, dan perilaku instrumental. Insting memberikan gambaran bahwa orang memiliki naluri alami untuk meniru tindakan orang lain (Levin \& Nolan, 1996).

Keluarga adalah sistem yang paling cepat dan mungkin paling berpengaruh yang mempengaruhi individu. Kurangnya bimbingan orang tua dan keluarga disfungsional terus ditekankan sebagai faktor risiko(Marais \& Meier, 2010). Rayment (2006) mengatakan bahwa orang tua tertentu yang menampilkan perilaku kasar dan agresif terhadap staf sekolah, juga menunjukkan tanda-tanda perilaku kekerasan, agresif dan antisosial dari anak-anak mereka. Ditemukan juga bahwa $10 \%$ responden mengaku sering melihat orang tua mereka bertengkar secara verbal atau fisik. Sangat masuk akal bahwa jika anak-anak dipertotonkan dengan tampilan agresif dari orang dewasa yang menjadi panutan mereka di rumah, mereka akan membawa pengalaman ini kemana saja termasuk ke sekolah.

\section{KESIMPULAN}

1. Perilaku disruftif sebenarnya perilaku yang biasa pada masa kanak-kanak, namun perilaku ini tetap perlu dikendalikan agar tidak meningkat dan berkembang lebih jauh.

2. Perilaku disruftif tidak hnya karena iklim sekolah, namun peran orang tua atau pengasuhan orang tua sangat 
penting untuk meminimalkan perilaku disrutif.

3. Orang tua adalah sebagai model yang kemungkinan besar akan ditiru oleh anak-anaknya, sehingga orang tua perlu berperilaku bijak, terutama ketika dihadapan anak-anaknya.

\section{REFERENSI}

Bidell, M. P., \& Deacon, R. E. (2010). School Counselors Connecting the Dots between Disruptive Classroom Behavior and Youth Self-Concept. Journal of School Counseling, 8, 1-30.

Bub, K. L., McCartney, K., \& Willett, J. B. (2007). Behavior problem trajectories and first-grade cognitive ability and achievement skills: A latent growth curve analysis. Journal of Educational Psychology, 99, 653-670.

Fantuzzo, J., Tighe, E., \& Childs, S. (2000). Family Involvement Questionnaire: A multivariate assessment of family participation in early childhood education. Journal of Educational Psychology, 92, 367-376.

Flicker, E. S., \& Hoffman, J. A. (2006). Guiding Children's Behavior: Developmental Discipline in The Classroom. New York: Teachers College Press.

Goldberg, W. A., \& Easterbrooks, M. A. (1984). Role of marital quality in toddler development. Developmental Psychology, 20, 504-514.

Kohn, A. (1999). Punished by Reward. Boston: Houghton Mifflin.

Levin, J., \& Nolan, J. F. (1996). Principles of Classroom Management: A Professional Decision-Making Model (2nd ed.). (2nd ed.). Bostonn: Allyn and Baco.

Mabeba, M. Z., \& Prinsloo, E. (2000). Perceptions of discipline and ensuing discipline problems in secondary education. South African Journal of Education, 20, 34-41.

Marais, P., \& Meier, C. (2010). Disruptive behaviour in the Foundation Phase of schooling. South African Journal of Education, $\quad 30(1), \quad 41-57$. https://doi.org/10.4314/saje.v30i1.5260 1

Morris, A. S., Silk, J. S., Steinberg, L., Myers, S. S., Robinson, L. R., Orleans, N., ... Steinberg, L. (2007). The Role of the Family Context in the Development of Emotion Regulation. Social Development, 16, 361-388. https://doi.org/10.1111/j.14679507.2007.00389.x

Putri, D. L. (2018, February). 5 Kekerasan Terhadap Guru yang Mencoreng Dunia Pendidikan, dari Dipukul Meja hingga Ada yang Tewas. Tribunstyle.com.

Rayment, T. (2006). Managing boys' behaviour. New York: MPG Books Ltd.

Reinke, W. M., Herman, K. C., Petras, H., \& Ialongo, N. S. (2008). Empirically derived subtypes of child academic and behavior problems: Co-occurrence and distal outcomes. Journal of Abnormal Child Psychology, 36, 759-770.

Ruholt, R., Gore, J. S., \& Dukes, K. (2015). Is Parental Support or Parental Involvement More Important for Adolescents?

Schroeder, C. S., \& Gordon, B. N. (2002). Depression. In C. S. Schroeder \& B. N. Gordon (Eds.), Assessment and treatment of childhood problems (2nd ed., pp. 377-416). New York: Guilford.

Stormshak, E. A., Bierman, K. L., McMahon, R. J., \& Lengua, L. J. (2000). Parenting practices and child disruptive behavior problems in early elementary school. Journal of Clinical Child Psychology, 29(1), 30-42. https://doi.org/10.1207/S15374424jccp 2901 
Strassberg, T. P., Kees, M. R., \& Drabick, D. A. G. (2002). Cognitive Response Repertoires to Child Noncompliance by Mothers of Aggressive Boys. Journal Of Abnormal Child Psychology, 30, 89-
101.

Todras, P. (2007). Teachers Perspective of Disruptive Behavior in the Classroom. Dessertation. Faculty of the Chicago School of Professional Psychology. 